\title{
Examining the Structure of a Multidisciplinary Engineering Capstone Design Program
}

\section{Mr. Bob Rhoads, The Ohio State University}

Bob Rhoads received his BS in Mechanical Engineering from The Ohio State University and his Masters in Business Administration from Regis University. He is also a P.E. He is the Engineering Capstone Program Coordinator for The Ohio State University.

\section{Dr. Clifford A Whitfield, Ohio State University}

Cliff Whitfield has a $\mathrm{PhD}$ in Aeronautical and Astronautical Engineering and is currently working as an Assistant Professor of Practice in the Mechanical and Aerospace Engineering Department and the Multidisciplinary Engineering Capstone Program for the Engineering Education Innovation Center at Ohio State University.

\section{Mr. Jacob T Allenstein, The Ohio State University}

Received a Master's Degree in Aeronautical and Astronautical Engineering at The Ohio State University in 2013 and a Bachelor's Degree in Aeronautical and Astronautical Engineering at The Ohio State University in 2011. Currently a Graduate Research Associate at the Aerospace Research Center (ARC) while an Instructor of Record for the first-year engineering program for the Engineering Education Innovation Center (EEIC) at The Ohio State University

\section{Dr. Peter Rogers, The Ohio State University}

Dr. Peter Rogers, Professor of Practice Engineering Education Innovation Center The Ohio State University Columbus, OH 43210 Rogers.693@osu.edu

Rogers joined the university in October, 2008 bringing with him 35 years of industrial experience. His career includes senior leadership roles in engineering, sales, and manufacturing in robotics, electronics, sensors, and controls industries. Throughout his career, Rogers has developed products using an innovative process consisting of multidisciplinary teams focused on understanding customer needs and converting them to commercially viable products and services. He brings this experience to the university where he leads the effort in developing company-sponsored, product-oriented Capstone design programs. As part of the mission of the Engineering Education Innovation Center (EEIC), Rogers has co-led the development of an ABET approved curriculum for a year-long Capstone experience. With a focus on providing students with a broader experience base, the multidisciplinary program applies teams of engineers, business, design, and other students to work with Ohio companies to help them be more competitive. Teams apply a company's core competencies to help develop new products and markets. This experiential learning emphasizes real-world problem solving, professional communication and ethics, teamwork, and implementation of a formalized design process. Additionally, Rogers has created the Social Innovation and Commercialization initiative by collaborating with business, engineering, and design colleges. Partnering with local non-profit organizations, teams define unmet problems working with people with various disabilities-problems that can be solved with an innovative product. The educational goal is to provide experiential learning with a social outreach. The social goal is to produce income to help non-profit partners become self-sustaining while improving the independence of people with disabilities. Rogers earned his PhD at the University of Massachusetts, Amherst focused on mechanical engineering and manufacturing. He has presented a number of industrial conference papers and holds several patents. He served as co-chair of the organizing committee for the 2012 Capstone Design Conference and is hosting the Conference at Ohio State in June 2014. He holds the position of Professor of Practice at The Ohio State University. 
Examining the Structure of a Multidisciplinary Engineering Capstone Design Program 


\begin{abstract}
The Engineering Education Innovation Center at The Ohio State University offers students an option to their traditional capstone design course by providing a Multidisciplinary Capstone Design course where teams work on company-sponsored projects. Teams include both engineering and non-engineering students and projects include product, process, and system design opportunities. This active learning opportunity allows students to apply their academic, professional, and practical skills to real-world problem solving. This two-semester program begins with a seven-week pre-capstone course. During this time the capstone coordinators form teams based on student preference and disciplines appropriate to the project scope. The coordinators assign a faculty advisor and identify an industry liaison to provide leadership and coaching throughout the project.
\end{abstract}

The program enhances critical thinking skills by providing open-ended projects. By following a basic engineering design process, students develop several critical professional skills including oral and written communication, professional working relationships, project and time management, and ethics along with a broad understanding of the interrelationship of business, engineering, and design elements. The design process includes: defining the problem, creating the requirements, creating design concepts, developing detailed specifications, creating a detailed design solution, building a prototype, validating the design, refining the design, documenting the design process, and identifying future recommendations. Teams deliver multiple design reports and formal oral presentations to the class, advisors, and industry sponsors.

The instructors continually solicit industry and departmental feedback to enrich the students' experience and better prepare them for their careers. We recently surveyed 370 graduates of the multidisciplinary program ranging in experience levels from one to five years. ${ }^{1}$ The survey compared the key needs of industry with the success of the program in meeting these needs. This paper addresses the quantitative results of the survey and describes the current program's structure. The authors focus on learning outcomes that include "an ability to function on multidisciplinary teams" (ABET Criteria 3d), "an ability to communicate effectively" (ABET Criteria 3g), and "the ability to manage an engineering project." The authors also compare the survey results of multidisciplinary alumni to the general population of engineering alumni to provide insight into the effectiveness of the multidisciplinary program in achieving industry needs.

\title{
Introduction
}

Capstone design courses are one way for engineering programs to meet the Accreditation Board for Engineering and Technology's (ABET) Criterion 5 which states: "Students must be prepared for engineering practice through a curriculum culminating in a major design experience based on the knowledge and skills acquired in earlier course work and incorporating appropriate engineering standards and multiple realistic constraints". Institutions across the nation meet this criterion in many different formats and structures. ${ }^{2}$ The Ohio State University offers 14 undergraduate engineering programs through ten engineering departments. Each program offers one or more capstone design options-representing a variety of capstone structures across the college-some are one- and others two-semester courses. Project topics are generated from 
faculty, research, or industrial clients. Projects are funded by departments, faculty research grants, or sponsor companies.

The Engineering Education Innovation Center (EEIC) at The Ohio State University offers a multidisciplinary engineering capstone experience as another option. This paper discusses the structure of the Multidisciplinary Engineering Capstone Program and alumni survey results of the program compared to the general population of engineering alumni.

\section{Multidisciplinary Capstone Program Structure}

The EEIC’s Multidisciplinary Capstone Program began in 2009 and has included over 450 students from 20 disciplines and 70 projects from over 50 different companies. The two-semester course begins with a seven-week pre-capstone session followed by a semester-and-a-half project. The projects are all realistic projects defined by sponsor companies who support the projects financially and with company personnel. Projects include process and equipment design, energy and environmental improvements, and new product development. Students from all 14 undergraduate engineering programs have participated in the program along with students from business, psychology, international studies, industrial design, dentistry, speech and hearing, occupational therapy, and food science. Many of the product development projects employ MBA students in the role of project manager.

Because the multidisciplinary capstone course is one of several options for senior engineering students, instructors can be selective when accepting students. They screen students through an application process that includes submitting a resume and application letter. Often, personal interviews are the deciding factor to ensure teams are formed with self-directed students. Students are asked to explain their interest in joining the program and to describe the contribution they expect to make to their team. During this process, the coordinators look for students exhibiting professional skills including time management, leadership, teamwork, communication, and initiative.

Capstone instructors recruit sponsoring companies and many are experienced, recurring partners. Instructors recruit through personal contacts, alumni referrals, Industry Liaison Office, and the development office. Many companies sponsor projects as a way of interviewing prospective employees. Some do so as a form of community promotion and some expect effective results from capstone projects that affect their bottom line.

The learning outcomes for the program are a vital part in preparing students for professional careers. Table 1 summarizes these outcomes.

\begin{tabular}{|l|l|}
\hline Outcome Name & Outcome Definition \\
\hline 1. Perform Professionally & $\begin{array}{l}\text { Students individually exhibit integrity, accept } \\
\text { responsibility, take initiative, and provide } \\
\text { leadership necessary to ensure project success } \\
\text { as part of a multi-discipline team. }\end{array}$ \\
\hline 2. Produce Quality Designs & Students collectively produce designs that \\
\hline
\end{tabular}




\begin{tabular}{|l|l|}
\hline & $\begin{array}{l}\text { meet important authentic performance } \\
\text { requirements while satisfying relevant } \\
\text { societal and professional constraints. }\end{array}$ \\
\hline $\begin{array}{l}\text { 3. Establish Team Relationships for Quality } \\
\text { Performance }\end{array}$ & $\begin{array}{l}\text { Students establish relationships and } \\
\text { implement practices with team members, } \\
\text { advisors, and clients that support high } \\
\text { performance and continuous improvement. }\end{array}$ \\
\hline 4. Manage Project Schedule and Resources & $\begin{array}{l}\text { Students plan, monitor, and manage project } \\
\text { schedule, resources, and work assignments to } \\
\text { ensure timely and within-budget completion. }\end{array}$ \\
\hline $\begin{array}{l}\text { 5. Apply Knowledge, Research and } \\
\text { Creativity }\end{array}$ & $\begin{array}{l}\text { Students utilize prior knowledge, independent } \\
\text { research, published information, patents, and } \\
\text { original ideas in addressing problems and } \\
\text { generating solutions. }\end{array}$ \\
\hline $\begin{array}{l}\text { 6. Make Decisions Using Broad-Based } \\
\text { Criteria }\end{array}$ & $\begin{array}{l}\text { Students make design decisions based on } \\
\text { design requirements, life-cycle } \\
\text { considerations, resource availability, } \\
\text { sustainability, and associated risks. }\end{array}$ \\
\hline 7. Use Contemporary Tools & $\begin{array}{l}\text { Students demonstrate effective use of } \\
\text { contemporary tools for engineering and } \\
\text { business analysis, fabrication, testing, and } \\
\text { design communication. }\end{array}$ \\
\hline 8. Test and Defend Design Performance & $\begin{array}{l}\text { Students collectively test and defend } \\
\text { performance of a multi-discipline design with } \\
\text { respect to at least one primary design } \\
\text { requirement. }\end{array}$ \\
\hline 9. Communicate for Project Success & $\begin{array}{l}\text { Students use formal and informal } \\
\text { communications with team members, } \\
\text { advisors, and clients to document and } \\
\text { facilitate progress and to enhance impact of } \\
\text { designs. }\end{array}$ \\
\hline Pursue Needed Professional Development & $\begin{array}{l}\text { Students individually assess and pursue } \\
\text { personal professional growth in concert with } \\
\text { project requirements and personal career } \\
\text { goals. }\end{array}$ \\
\hline
\end{tabular}

Table 1: Program's Learning Outcomes ${ }^{3}$

The pre-capstone course (first seven weeks) focuses on teaching a design process in a lecture setting while teams of three or four students apply it to a mini-design project. The design is then followed throughout the company-sponsored project (Figure 2.) 


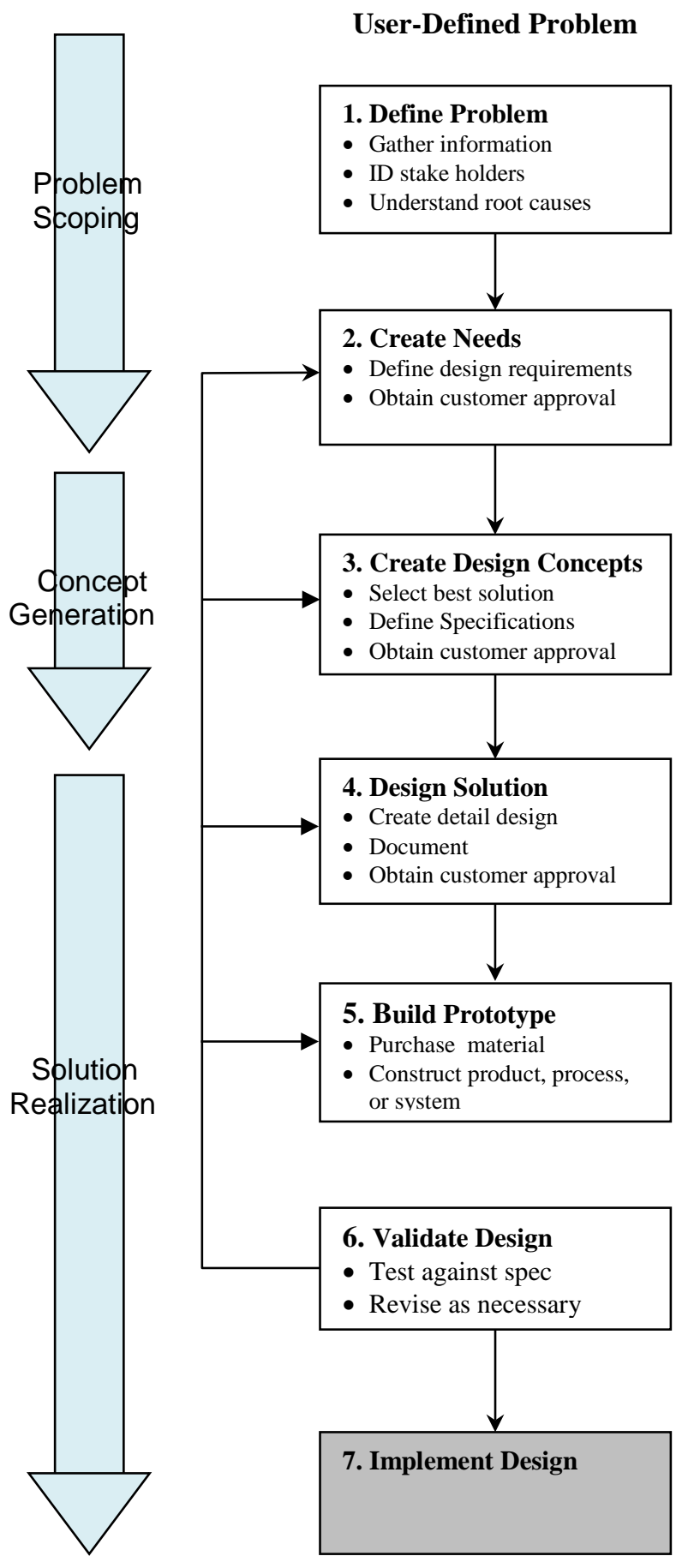

Figure 2: Engineering Design Process ${ }^{3}$

To familiarize students with the design process, they perform a mini-design project in the precapstone course. This involves redesigning a home product (i.e. toaster, fruit slicer, contact lenses case, etc.) to address a common functional issue. Written and oral presentations are required at each phase of the project—each assessed with a set of rubrics (Appendix, Table A-1 and A-2). In addition to teaching the design process, lectures include topics on project 
management, teamwork, communication, ethics, creative thinking, and design for commercialization.

Upon completion of the pre-capstone portion, teams are selected and matched with a companysponsored project. Teams typically consist of three to six students matched to the needs and scope of the project. To help ensure enthusiastic participation, clients present their project overview to all students and students rank the projects in order of interest. They are assigned according to their preference ensuring that each team has the disciplines to match the project need. The company assigns an employee (typically an engineer directly associated with the project) to the team of students to act as a liaison, coach, and subject-matter expert. Capstone instructors recruit faculty advisors for each project who are compensated from project funds. A faculty mentor advises no more than two projects. Oral and written assignments are due at each of the major design steps and are graded as an average of the faculty advisor and one of the project instructors to provide a "normalizing” affect. To ensure consistency between graders, instructors apply common rubrics (see Appendix, Table A-1 and A-2). Grades for the course are weighted $90 \%$ for team contribution and $10 \%$ for individual effort.

Throughout the project, students interact with the company liaison and faculty advisor in several ways. Each team meets with their advisors and company liaison once per week. Written agendas guide the update of status, identification of obstacles and resources needed, and a summary of next tasks. These meetings take on different forms but teams typically use teleconference or videoconference means. At each project milestone, teams make a formal presentation to the client, often at the client's facility. Finally, students interact with the sponsor and mentor thru plant visits and email communications.

\section{Survey Methods and Respondents}

The Ohio State University's College of Engineering (COE) has surveyed alumni regarding ABET Objectives and Outcomes since 1999. In 2012, the college surveyed second- and thirdyear engineering alumni. The survey includes both college-common and program-specific outcomes. ${ }^{4}$ Of the 1,376 surveys sent, the college received a response rate of $22.9 \%(n=315)$. This paper focuses on the college-common outcomes section of the survey and the surveyed alumni responses relating their academic preparation to the importance to their professional career.

In 2012, the EEIC's surveyed 370 multidisciplinary capstone (MDC) alumni. The survey focused on the learning objectives of the multidisciplinary capstone and their impacts on recent alumni's (2008-2012 graduates) careers. The survey follows a similar process and structure as the college survey of the general graduate population. The MDC alumni survey includes the college's common-outcomes section relating the surveyed alumni responses to ABET Criteria 3 preparedness and importance to their professional career. Of the 370 surveys sent out, the Engineering Education Innovation Center received a response rate of 19.4\% ( $n=66)$. 


\section{Survey Results and Discussion}

This section details and discusses the results of the MDC survey and compares equivalent years of graduates that participated in the MDC survey to the results of the larger COE alumni pool. The categories discussed include the four learning outcomes:

- “an ability to function on multidisciplinary teams" (ABET Criteria 3d),

- "an ability to communicate (written) effectively" (ABET Criteria 3g),

- "an ability to communicate (orally) effectively" (ABET Criteria 3g), and

- "the ability to manage an engineering project."

All survey respondents rated each category from one to five. One indicates either Not Important to one's professional career or Did Not Contribute in academic preparation and five indicates Extremely Important or Extremely Helpful.

\section{Overall Results}

The averaged ratings for the early career (years 1-5 after graduation) MDC-specific alumni are shown below for the four learning outcomes.

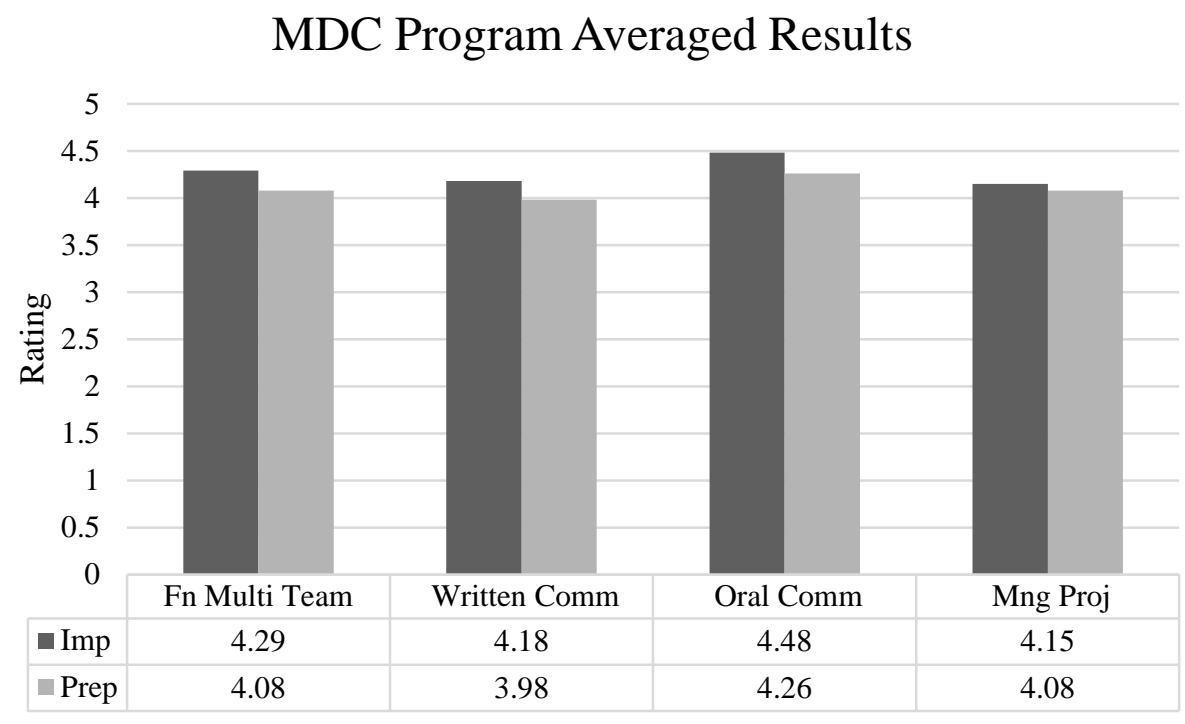

Figure 3: MDC Program Averaged Results

There are two main considerations when examining the above results. The first is recognizing that the results are averaged over alumni with one to five years of experience and the views of importance to their professional career and their academic preparation for first-year alumni may be different than alumni with five years of experience. The second is that the results include alumni who participated in the inaugural years of the program and those who graduated more recently with the benefit of program improvements including curriculum material and delivery, expansion of student disciplines, and growing experience of staff and industry-sponsors. 
With these considerations in mind, it is nevertheless positive to note that over the first five years of existence, the multidisciplinary program received a rating of four or better in academic preparation for the averaged results over the four categories. Furthermore, the program provided reasonable academic preparation when comparing it to the importance to professional career ratings, with the greatest difference being 0.22 .

Consider the survey results when comparing the MDC subgroup results to the larger COE alumni pool responses for corresponding graduating classes. The MDC alumni, also being part of the larger COE population, may have responded to both surveys one year apart. For the same two graduating classes surveyed by the COE, the MDC response rate for the 105 alumni that participated in the program-specific survey was $22.8 \%(n=24)$.

\section{MDC and COE Survey Results Comparisons}

Consider the responses of the two groups that relate the professional importance and academic preparation with their ability to function on a multidisciplinary team (ABET Criteria 3d), shown below.

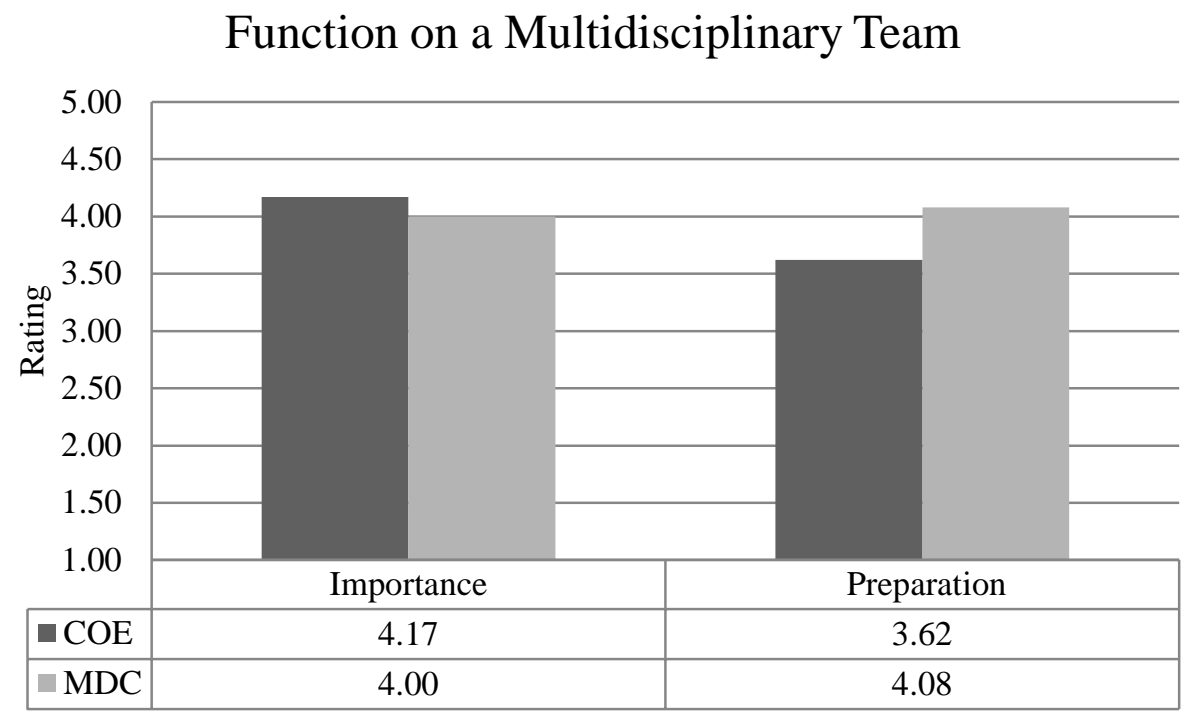

Figure 4: MDC and COE Comparison with the Ability to Function on a Multidisciplinary Team

There is a marginal difference between the two groups of students for "importance of the ability to their professional career", but the MDC alumni subgroup indicated an $11.3 \%$ increase in "academic preparation" over the COE alumni pool. Considering that one of the main objectives of the MDC program is to grow this skill, the results are positive feedback for the MDC program.

The comparison results for the ability to communicate effectively (ABET Criteria 3g) are shown in the following two figures. 


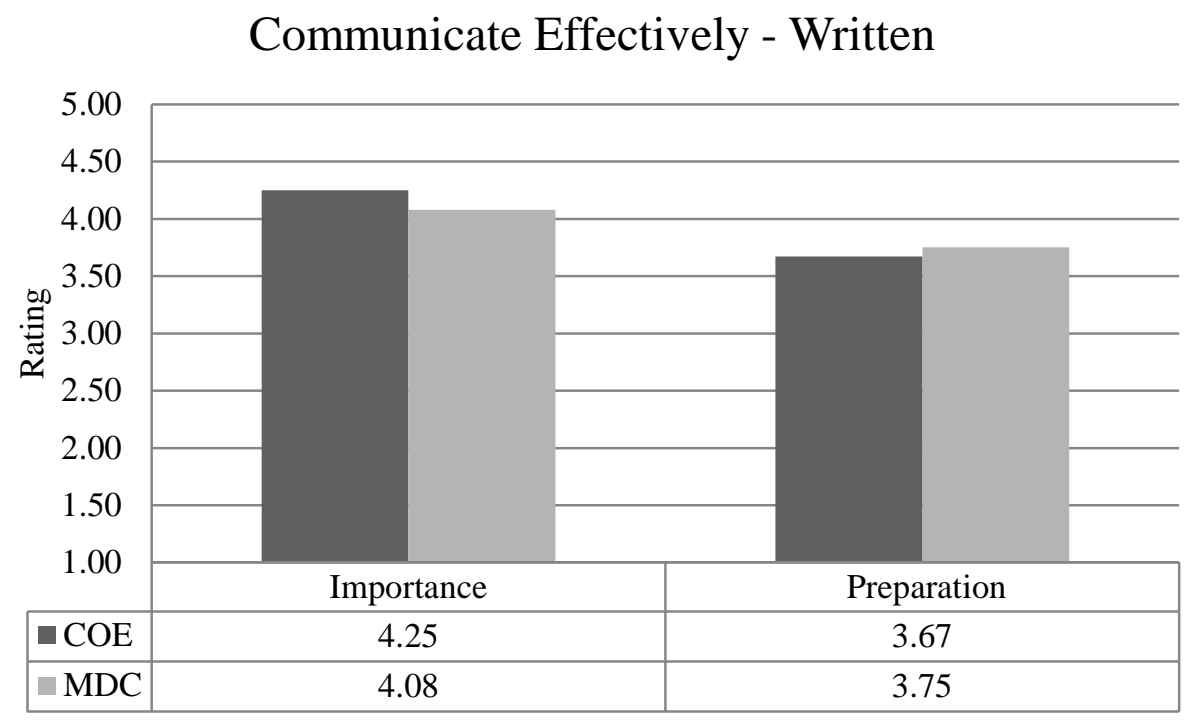

Figure 5: MDC and COE Comparison of Effective Communication - Written

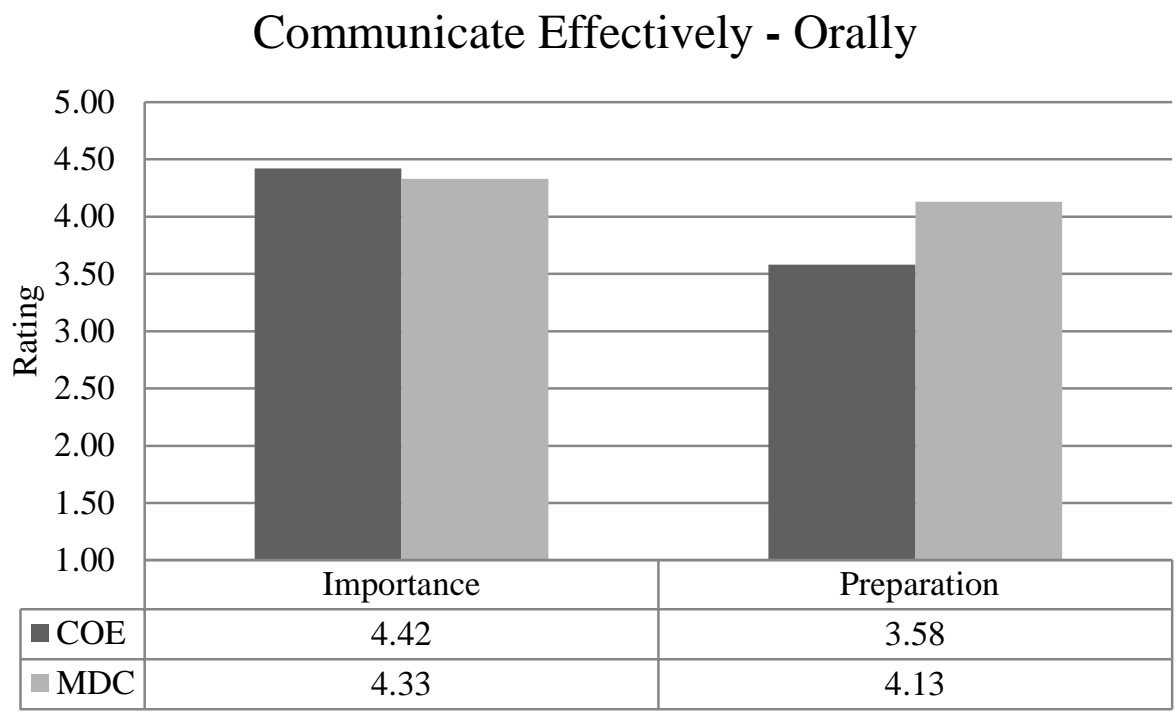

Figure 6: MDC and COE Comparison of Effective Communication - Orally

Figure 5 and 6 indicate that the MDC subgroup was consistent with the larger COE alumni in regard to the importance to their professional careers in both forms of communication. There was a marginal increase of 0.08 in rating for the MDC alumni's academic preparation in effective writing communication. However, the results indicate a more noticeable increase in rating of 0.55 with their preparation to effectively communicate orally. The rating increased from 3.58 for the general COE group to 4.13 for MDC alumni, a 13.3\% improvement.

Contributing factors of this improvement could be attributed to the programs curriculum emphasis on developing oral communication skills. The program provides a number of 
opportunities to make formal oral presentations couple with formative and summative assessment. Additionally, oral communication skills are developed through weekly status meetings with the client. However, the COE discipline-specific capstone programs may offer similar experiences, which could indicate that the improvement may also include the way in which the program presents and assigns value to curriculum material that emphasizes developing oral communication skills.

The results for the survey question regarding "the ability to manage an engineering project" are shown below.

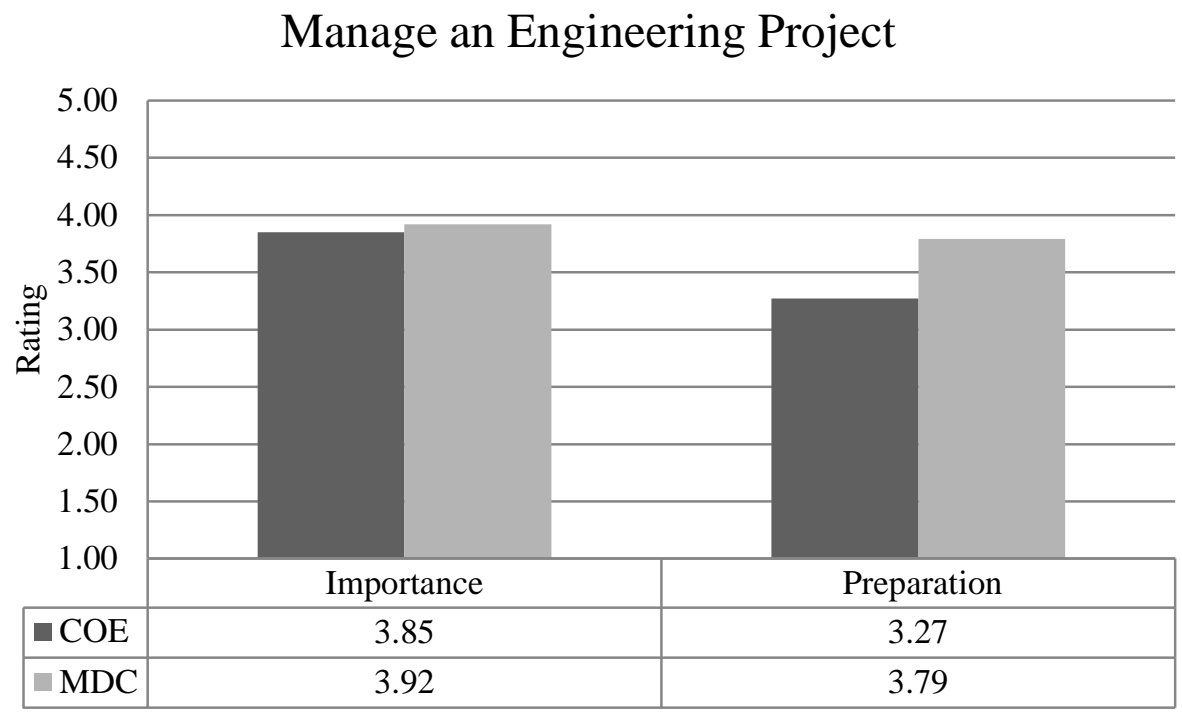

Figure 7: MDC and COE Comparison of an Ability to Manage an Engineering Project

There is a noticeable increase of $13.7 \%$ in the academic preparation of the MDC alumni compared to the larger $\mathrm{COE}$ group, and similar ratings in the importance to professional career. Each project team is required to meet specific milestones at fixed dates. Teams quickly learn that managing time and tasks is critical to meeting assignment dates. Project status is continually addressed and monitored by both faculty advisor and industry liaison at weekly meetings placing a great visibility on the results of task completion.

The authors observe that the four learning outcomes are rated lower by the general COE alumni than MDC alumni. The difference between these two groups for academic preparation ranged from 0.12 to 0.54 , with the greatest difference observed to be with the ability to function on a multidisciplinary team. Also, the results identified the most important category to professional careers was effective oral communication; the MDC alumni had an average rating in academic preparation of 4.13 while the COE alumni had an average rating of 3.58 .

\section{Plans for Improvement}


While the survey results show positive results in several learning outcomes, the capstone coordinators continue to monitor feedback from industry, faculty and anecdotal feedback from graduating seniors. In addition to The Ohio State University's internal survey responses, the capstone coordinators look at successes of other institutions and trends in engineering education. ${ }^{5}$ In order to meet the objectives of continuous improvement, the MDC capstone coordinators continue to improve the capstone program by adapting the following concepts:

- Implementing "flipped classroom” techniques and spending more class time working with teams

- Extending capstone design to a full two semesters to provide more time for design validation

- Working with various programs to extend design concepts throughout all four years

- Developing technical writing course taught within the college of engineering

- Incorporating “design thinking” concepts and "user-centered" design

- Focusing on environmental, social, and global impacts of design

\section{Conclusion}

The Ohio State University’s Multidisciplinary Capstone Program challenges student to apply their academic and professional experiences to industry-sponsored projects. The program gives students an opportunity to develop skills in project management, professional communication and application of a design process to a real-world project in a multidisciplinary team environment.

This paper described the current Engineering Education Innovation Center’s Multidisciplinary Capstone program's structure and addressed the quantitative results of an alumni survey. The authors focused on learning outcomes that include "an ability to function on multidisciplinary teams” (ABET Criteria 3d), "an ability to communicate effectively” (ABET Criteria 3g), and "the ability to manage an engineering project." The survey asked the alumni to rank these four outcomes relating their academic preparation to the importance to their professional career. The authors compared the survey results of multidisciplinary alumni to the general population of engineering alumni to provide insight into the effectiveness of the multidisciplinary program in achieving industry needs. The response rate for the two alumni surveys was $22.8 \%(n=24)$ and $22.9 \%(n=315)$, respectively.

Overall, the authors observed that the multidisciplinary capstone respondents recognized the program as providing reasonable academic preparation for the four learning outcomes when comparing them to the importance to professional career ratings. When comparing the multidisciplinary respondents to the general population of engineering alumni, the multidisciplinary alumni rated all four outcomes higher in importance and preparation when compared to the general engineering population.

The authors also discussed their continuous improvement concepts to help improve the student's capstone experience and to better prepare them for their future professional careers. The authors are introducing new curriculum delivery concepts, emphasizing design concepts and extending the length of the industry-sponsored project. 


\section{References}

1. Howe, S., "Where Are We Now? Statistics on Capstone Courses Nationwide”, Advances in Engineering Education, Spring 2010

2. Rhoads, B., Rogers, P. “Multidisciplinary Capstone Design Guide”, Engineering Education Innovation Center, College of Engineering, The Ohio State University.

3. Allenstein, J.T., Whitfield, C.A., Rhoads, B., Rogers, P., "Examining the Impacts of a Multidisciplinary Engineering Capstone Design Program", Proceedings of the 2013 American Society for Engineering Education Annual Conference, Atlanta, Georgia, June 2013.

4. College of Engineering 2012 Outcomes Committee Alumni Survey Report, 27 November 2012. [http://engineering.osu.edu/sites/eng.web.engadmin.ohio-state.edu/files/uploads/2012_alumni_survey_ report_27_nov_0.pdf]

5. "Phase I: Synthesizing and Integrating Industry Perspectives”, Transforming Undergraduate Education in Engineering, May 9-10, 2013 NSF/ASEE Workshop Report

6. Allenstein, J.T., Whitfield, C.A., Rhoads, B., "From the Industry to the Student: Project Management of an Industry-Sponsored Multidisciplinary Capstone Project", Proceedings of the 2012 American Society for Engineering Education Annual Conference, San Antonio, Texas, June 2012. 


\section{Appendix}

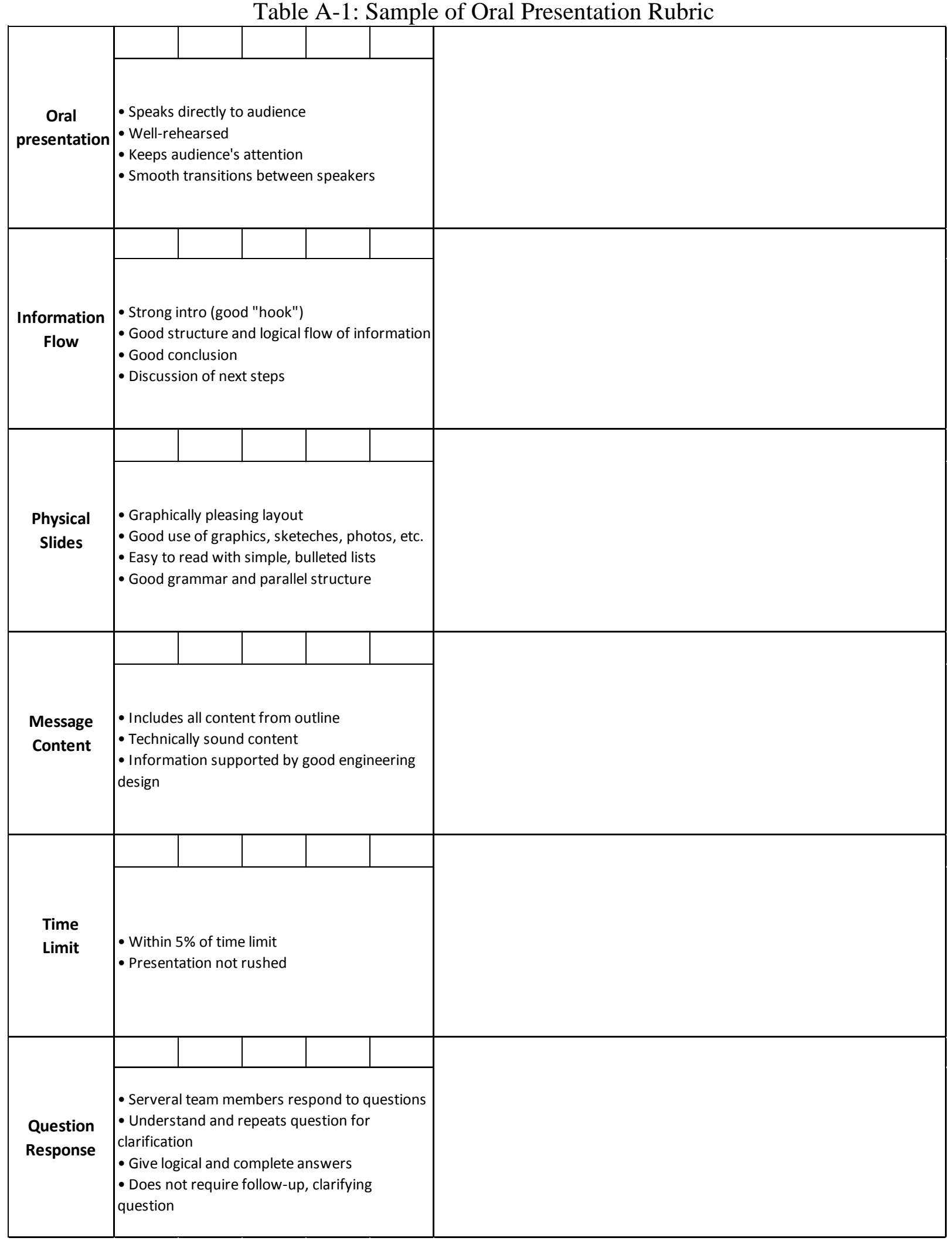


Table A-2: Sample of Written Documents Rubric

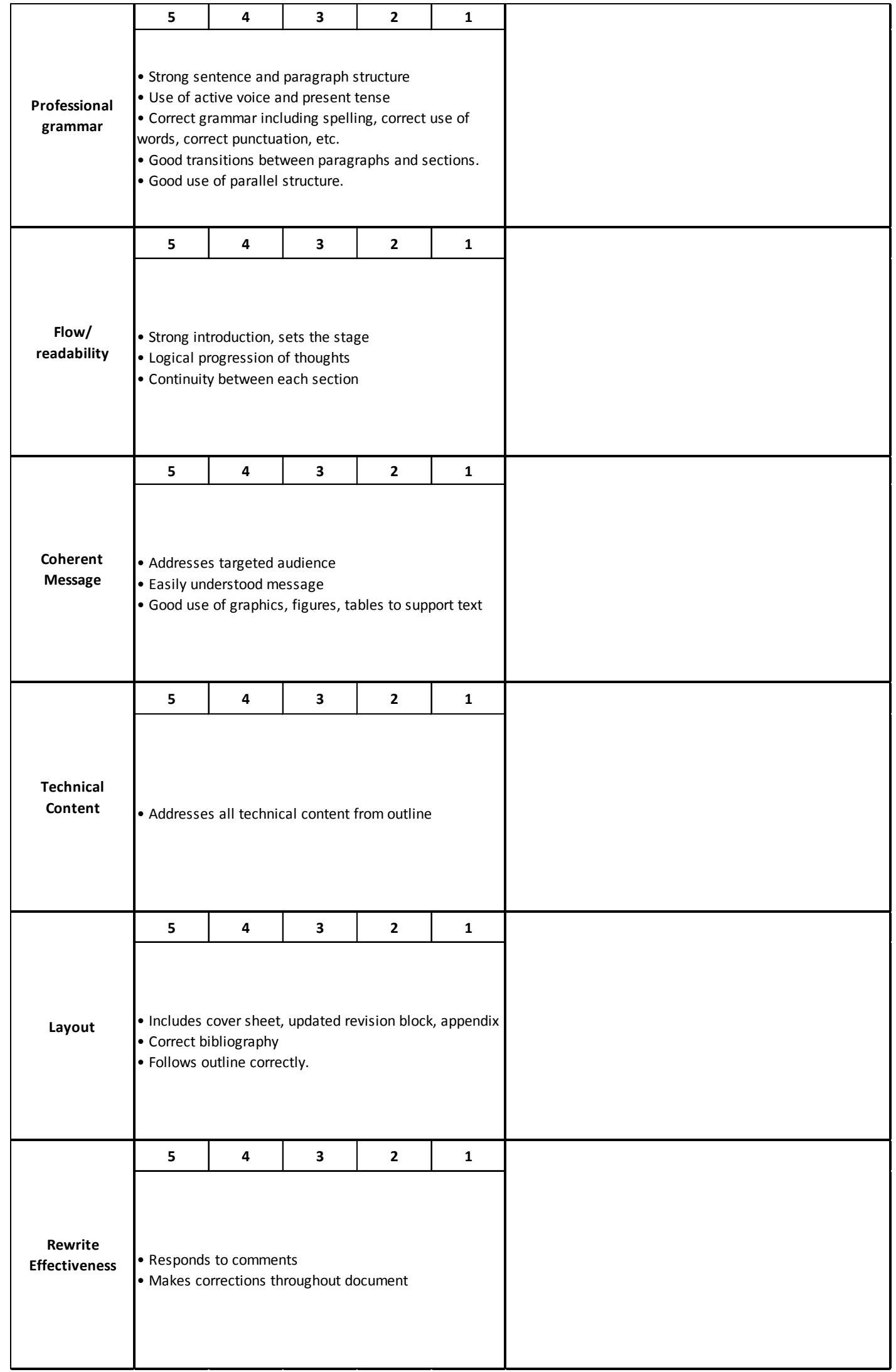


Table A-3: Sample of Survey Questions

Multidisciplinary Engineering Capstone Program Survey Questions:

1. What year did you take Engineering 659: Multidisciplinary Capstone Program?

2. What is your current employment status?

3. In what program did you earn your bachelor's degree?

4. Did you have any non-engineering students on your team?

5. Rate its importance to your CAREER (1-Extremely Important to 5-Not Important)?

a. Design and Conduct Experiments

b. Analyze and Interpret Data

c. Design a system component, or process to meet a desired need within realistic constraints

d. Function on a Multidisciplinary Team

e. Function on a culturally and ethnically diverse environment

f. Manage an engineering project

g. Identify, formulate, and solve engineering problems

h. Communicate effectively orally in presentations, meetings, etc.

i. Communicate effectively in writing letters, technical reports, etc.

$\mathrm{j}$. Recognize the need for and engage in life-long learning

$k$. Use techniques, skills and modern engineering tools

l. Use computing technology

6. Rate its Contribution to your preparation resulting from your CAPSTONE EXPERIENCE (1Extremely Helpful to 5-Did Not Contribute)?

a. Design and Conduct Experiments

b. Analyze and Interpret Data

c. Design a system component, or process to meet a desired need within realistic constraints

d. Function on a Multidisciplinary Team

e. Function on a culturally and ethnically diverse environment

$\mathrm{f}$. Manage an engineering project

g. Identify, formulate, and solve engineering problems

h. Communicate effectively orally in presentations, meetings, etc.

i. Communicate effectively in writing letters, technical reports, etc.

$\mathrm{j}$. Recognize the need for and engage in life-long learning

$k$. Use techniques, skills and modern engineering tools

l. Use computing technology

7. Did the Capstone Experience help ...

a. Have a successful interview

b. Obtain your first job after graduation 
c. Transition into your first job assignment

d. Provide career advancement opportunities

8. Would you recommend the Multidisciplinary Capstone?

9. Why or why not in regards to your answer in Question 8?

10. How could we improve the MULTIDISCIPLINARY CAPSTONE experience? 